\title{
SOBRE A RELAÇÃO ENTRE EPISTEMOLOGIAS E A ROSA DOS VENTOS.
}

\section{Professor aposentado pela PUC-SP douglassangeog@gmail.com}

Recebido para publicação em 15/09/2018 e aceito em 18/11/2018

DOI: $10.12957 /$ tamoios.2018.38509

Tenho acompanhado com alguma distância as proposições do sr. Boaventura de Souza Santos desde seu Pela Mão de Alice ${ }^{1}$ e seus esforços em justificar, identificar ou redefinir os diferentes significados de pós modernidade. Sem dúvida trata-se de um dos autores portugueses contemporâneos dos mais prolixos quando se trata de temas associados a política, sociologia, filosofia ou algo que possa ter algum nome associado a esses. Nas últimas semanas, um de seus $\operatorname{artigos}^{2}$ chamou minha atenção a ponto de provocar a necessidade de tecer comentários diretos sobre suas proposições: o que trata do conceito de Iluminismo e retoma a noção de uma epistemologia do sul.

Para dialogar com o texto de Souza Santos, acabei optando pelo caminho mais longo e tortuoso (principalmente para aqueles que, como eu, já leram o texto aqui comentado): resolvi acompanhar parágrafo por parágrafo, proposição por proposição, inserindo aqui e ali os comentários que considerei pertinentes. Os textos de Souza Santos estão em itálico.

Em busca de outros iluminismos

A conhecida revista de arte norte-americana Artforum solicitou-me um curto texto sobre o tema "O que é o Iluminismo?" Este é o título do famoso texto de Immanuel Kant publicado em 1784, glosado desde então por muitos autores, inclusivamente por Michel Foucault. A editora da revista queria especificamente que eu abordasse o tema a partir da minha proposta das epistemologias do sul (Epistemologies of the South: Justice against Epistemicide. Nova Iorque, Routledge, 2014; The End of the Cognitive Empire: The Coming of Age of the Epistemologies of the South. Durham, Duke University Press, 2018.). Eis a minha resposta.

A primeira constatação que podemos fazer é que o objetivo do artigo é abordar o iluminismo a partir do que o sr. Souza Santos chama de epistemologia do Sul e tendo como referência primária um texto de Kant, o qual teria como objetivo explicitar o significado do movimento encabeçado por intelectuais europeus a partir do século XVIII. Aqui se inicia ${ }^{3}$ o estranhamento. Imaginemos que nenhum de nós leu os livros que aqui estão citados com seus títulos em inglês. Creio que a reação mais imediata é a pura e 
simples surpresa: qual seria a associação entre a epistemologia e a rosa dos ventos? O Sul é uma direção ou um lugar? Ou por ser uma coisa é também a outra? Provavelmente a última pergunta seria, igualmente, a resposta. Acontece, no entanto, que seria necessário identificarmos a existência de epistemologias umbilicalmente associadas à direção/lugar em que são produzidas e justificar por que a teoria do conhecimento produzida no Sul deve ser melhor do que a produzida em qualquer outro ponto da Rosa dos Ventos. Isso, certamente, será uma tarefa difícil de ser realizada, principalmente na escala que uma proposição como essa exige. Observemos que se trata de "epistemologias", algo que se expressa na pluralidade das diferentes manifestações culturais, a princípio, de uma direção/lugar genericamente definida(o) como Sul. Como o leitor atento já deve ter identificado, estou aqui trocando a palavra "epistemologia" por "cultura" e o faço com o objetivo de carregar a proposição do sr. Souza Santos de algum significado mais ou menos compreensível. Em linhas muito gerais (creio que suficientes para os comentários que faço), entende-se por epistemologia a reflexão sistemática sobre os processos que permitem ao sujeito construir um conhecimento, enquanto que a noção de cultura parece carregar sempre uma dimensão muito mais ampla do processo civilizatório: envolve os fundamentos comportamentais que, conscientes ou não, permitem a um povo - e, portanto, aos seus indivíduos - reconhecer em suas relações uma identidade que produza e reproduza o sentimento de pertença ${ }^{4}$. Podemos afirmar que uma epistemologia é uma das criações possíveis de uma cultura, se considerarmos que se trata de uma reflexão sobre o ato de refletir e que isso só faz sentido se nos atermos à teoria do conhecimento como um ato de cultura.

Colocando a discussão nesses termos, talvez possamos considerar que diferentes culturas possuam, necessariamente, diferentes epistemologias. Que os povos cossacos não possuam as mesmas formulações lógicas dos monges que vivem no Tibet e, mais do que isso, que assumam tal diferença conscientemente, sistematizando as bases sobre as quais constroem seus postulados; nesse contexto, os cossacos defenderiam verdades que nem ao menos poderiam ser compreendidas pelos povos que vivem na península ibérica ou na Escandinávia. Se nossa constatação é correta, podemos ampliá-la para a parte do mundo hoje conhecida como América do Norte e teremos povos que sobrevivem em meio a recuos e avanços na tentativa de manter vivo o modo de pensar de tribos as mais diferentes ${ }^{5}$. Talvez o primeiro problema desse raciocínio seja que todos os povos e lugares citados ficam no hemisfério norte. O segundo é o fato de que cada uma das culturas citadas se confunde com o lugar em que se materializam, mas efetivamente tal identidade pouco ou nada tem a ver com a rosa dos ventos. Cada um desses povos está, de seu respectivo ponto de vista, no centro do seu próprio mundo (não podemos estar ao sul ou ao norte de nós mesmos). Os outros é que vivem ao sul, ao norte ou em qualquer outra direção identificável pelo observador (considerando que nem sempre o sistema de 
referência direcional/topológico é o mesmo). Como certamente sabe o sr. Souza Santos, viver em Portugal e ser um alentejano é assumir como identidade a leitura que os portugueses econômica e militarmente hegemônicos fizeram dos que vivem do "outro lado do Tejo" ou, para ser mais preciso, "para além do Tejo" e, sem dúvida, o mesmo podemos afirmar daqueles que se reconhecem como transmontanos. Assumir-se como alentejano ou transmontano é olhar para si mesmo com "o olhar do outro", da mesma maneira que um asiático, vivendo na Ásia, reconhecer-se como oriental. Um outro exemplo está associado ao uso de mapas que possuem no meridiano de Greenwich sua centralidade, nos obrigando a olhar o mundo a partir de um sistema de referência cuja justificação matemática não esconde uma presunção colonialista. A placa que se encontra logo na entrada do observatório, afirmando que ali é o centro do espaço e do tempo do mundo, é um aviso a todos os povos de qual deve ser o sistema de referência que todos devemos usar para olharmos para nós mesmos.

Mudando de hemisfério... os aborígenes australianos e os povos indígenas sulamericanos, além dos povos que vivem ao sul do continente africano, são os exemplos disponíveis quando nos concentramos no hemisfério Sul. Aí retomo a pergunta original: haveria, de fato, epistemologias do Sul? A sul de onde? Que lugar é esse quando transformamos uma direção em uma área? Estar ao Sul do Equador é uma identidade? Se o é, quem seriam os sujeitos que identificam a si próprios e/ou aos outros com tais parâmetros? Que dizer dos povos ao norte da África ou dos latinos associados com as sociedades tribais ao norte da Amazônia, América Central e México? Como fazer para que a direção Sul seja capaz de identificar uma maneira de pensar diferenciada e, mais do que isso, diferenciada em relação a quê ou a quem? As populações que vivem em cidades como São Paulo, Buenos Aires, Montevideo, Santiago, Rio de Janeiro e tantas outras, poderiam ser chamados de "povos do Sul"? Ou tal identidade se associa somente aos povos indígenas ou àqueles que, de uma maneira ou de outra, estão dissociados da cotidianidade subsumida ao capitalismo?

Continuemos...

Em 1966, um dos mais inovadores intelectuais ocidentais do século XX, Pier Paolo Pasolini, escreveu que somos muitas vezes prisioneiros de palavras doentes. Referia-se a palavras que parecem plenas de sentido, mas que, de fato, estão desprovidas dele ou, talvez mais precisamente, palavras que possuem conotações vagas e misteriosas, mas nos deixam muito inquietos, dada a sua aparência de estabilidade e coerência. Pasolini refere três palavras doentes - cinema, homem e diálogo-, insistindo no fato de existirem muitas mais. Penso que uma delas é Iluminismo. Foucault mostrou já que somos prisioneiros desta palavra. Contudo, na sua obsessão com a ideia de poder, não 
reconheceu que os prisioneiros nunca estão totalmente aprisionados e que a resistência nunca é apenas determinada pelas condições impostas pelo opressor. Afinal, as conquistas revolucionárias dos protagonistas do Iluminismo europeu mostram-nos precisamente isso. Devemos então começar a partir do ponto em que Foucault nos deixou. Poderemos nós curar essa palavra doente? Duvido que possamos. Contudo, se houver uma cura, ela ocorrerá, sem dúvida, contra a vontade do doente.

A leitura desse parágrafo, de forma imediata, não me leva a Pasolini e tampouco a Foucault. Quem me vem à memória é Saramago e a necessidade que ele identificava de descarnarmos as palavras, tirar delas toda a cobertura e verificar se seu significado diz, de fato, o que queremos dizer. Não me recordo a página, mas, certamente, li isso em seus maravilhosos Cadernos de Lanzarote. Contudo, quer nos refiramos a Pasolini, Foucault ou Saramago, ou mesmo ao próprio Souza Santos, para além do fato de estarmos falando de europeus latinos (será que isso importa?), tais escolhas são sempre arbitrárias, tanto da minha parte quanto daquela do autor do texto em pauta. Afirmar que Pasolini foi um dos mais inovadores intelectuais do século XX é, de fato, pura arbitrariedade. Muitos e muitos intelectuais foram ao menos tão inovadores quanto Pasolini, e a escolha de Souza Santos está associada à noção de que existiriam palavras doentes (que é o que de fato ele quer afirmar) e não à condição inovadora do cineasta italiano. Afirmar que ele foi um dos intelectuais mais inovadores do século XX objetiva apenas incorporar algum tipo de legitimidade, autoridade e presunção de verdade à afirmação que Souza Santos quer utilizar $^{6}$.

Acontece que o parágrafo não se encerra em Pasolini, pois o que se deseja é, ao se identificar que há palavras doentes, fazer uso de Foucault para chegar ao reconhecimento de que há palavras de que somos prisioneiros; assim, juntando Pasolini com Foucault, temos o fato de que somos prisioneiros de palavras doentes. Souza Santos dá continuidade ao seu raciocínio acusando Foucault de ser prisioneiro da sua ideia de poder (outra palavra doente?) e, portanto, estar bloqueado no interior da armadilha que buscava denunciar. Resultado? Há de se curar o doente independentemente de ele reconhecer estar nessa condição, ou até mesmo à sua revelia.

A afirmação que encerra o parágrafo é, de fato, um ponto de partida de algo profundamente perigoso. Curar as pessoas de suas ignorâncias (o domínio que sobre elas exercem as palavras doentes) é, a princípio, o discurso dos que defenderam que o papel do colonizador é curar os selvagens de suas selvagerias.

Mas Souza Santos não se limita a algo tão simplório. Ele tenta desenvolver um certo tipo de reconhecimento da relação dialética entre o doente e a doença, algo semelhante às 
proposições feitas por Hegel quando tenta discutir a dialética entre o Senhor e o Escravo. O que não transparece no desenrolar desse tipo de dialética (diferentemente de Hegel) é a presença do conceito. Curar palavras é curar o que pensamos, imaginamos, associamos ou, por fim, conceituamos quando as utilizamos. Assim, dois movimentos precisam ser feitos: é preciso provar que o conceito que temos está doente e, para além disso, é preciso propor um conceito novo que esteja liberado dos vícios ou problemas que foram identificados. Seria essa a intenção do sr. Souza Santos com suas epistemologias do Sul? Provavelmente, mas vale considerar que as palavras sem conceitos são vazias e utilizálas dessa maneira (já diria o próprio Hegel) tem por objetivo enganar os ouvintes ou leitores. De toda maneira, Souza Santos não parece ser muito otimista quanto à possibilidade de curar as palavras doentes. Isso decerto nos obrigaria a imaginar que, se não podem ser curadas, devem ser eliminadas ou então devemos nos conformar que sobrevivam enquanto possam... Até onde é possível utilizarmos desse tipo de recurso literário para falarmos de epistemologias ${ }^{7}$ ?

De toda maneira, é em busca de um conceito que o texto tem sua continuidade.

Se perguntarmos a um budista o que é o Iluminismo, poderemos obter uma resposta como a de Matthieu Ricard, um monge que vive no Nepal. Para Ricard, Iluminismo implica:

Um estado de conhecimento ou sabedoria perfeitos, aliado a uma infinita compaixão. Neste caso, o conhecimento não significa somente a acumulação de dados ou uma descrição do mundo dos fenómenos até aos mais ínfimos pormenores. O Iluminismo é uma compreensão tanto do modo relativo da existência (a forma como as coisas se nos apresentam) como do modo último da existência (a verdadeira natureza dessas mesmas aparências). Tal inclui as nossas mentes, bem como o mundo exterior. Esse conhecimento é o antídoto básico para a ignorância e o sofrimento.

Fico tentando imaginar qual teria sido o objetivo de Souza Santos ao iniciar o processo de construção conceitual para identificar o significado de Iluminismo chamando para o embate um Monge Budista. Será que estamos falando do mesmo Iluminismo, aquele movimento encabeçado na Europa por intelectuais dos séculos XVIII e XIX, envolvidos de alguma maneira com o enciclopedismo, com o romantismo alemão e com o pragmatismo (empirismo) inglês? Será que podemos associar as noções de luz, conhecimento, sabedoria e compaixão cunhadas no interior das culturas centro europeias com as mesmas palavras utilizadas por um monge budista de nome e sobrenome com sotaque francês?

Creio que a mesma pergunta se fez Souza Santos no parágrafo seguinte: 
Até que ponto o Iluminismo de Ricard é diferente do de Kant, Locke ou Diderot? Ambas as concepções implicam uma ruptura com o mundo tal como ele nos é dado. Ambas exigem uma luta contínua pela verdade e pelo conhecimento, sendo que o seu objetivo último equivale a uma revolução - uma revolução interior, no caso do Iluminismo budista, e uma revolução social e cultural, no caso do Iluminismo europeu. Será que existem continuidades entre essas rupturas, tão distantes em termos das suas gêneses e dos seus resultados? Devemos considerar como dado adquirido que nos conhecemos a nós ao conhecermos o mundo, conforme nos promete o Iluminismo europeu, ou devemos antes partir do pressuposto de que conhecemos o mundo uma vez que nos conheçamos a nós, conforme a promessa do Iluminismo budista? Qual dos dois pressupõe a tarefa mais impossivel?

Souza Santos, certamente, não precisaria ir tão longe para fazer os mesmos questionamentos. Uma ou outra citação no chamado Novo Testamento nos indicaria ser Cristo "o Caminho, a Verdade e a Vida"; nos informaria de que somente a "Verdade nos libertará" ou criaria alguma relação entre Cristo e a Luz. Igualmente, a partir de textos clássicos como A República de Platão ou o Organon de Aristóteles (usando sempre de algum arbítrio, deixemos outros autores de fora) Souza Santos teria mais duas diferentes maneiras de se entender o significado de verdade e da associação entre a busca do conhecimento e a ideia de luz, iluminação, clarividência e coisas do tipo - e, no caso do Organon, da própria lógica como ferramental necessário dessa mesma busca. Como todos sabemos, o cristianismo e suas derivações gregas são muito mais familiares aos iluministas europeus do que aos monges budistas.

De toda maneira, o iluminar budista, nos seus séculos de existência, possui assumidos fundamentos metafísicos que o iluminismo centro europeu procura negar, ou ao menos esconder, em nome de uma proposição genérica chamada "ciência", uma espécie de evocação que poderia ser observada sob múltiplas perspectivas. A primeira delas é a ideia de ser ciência um substantivo, isto é, uma coisa que precisa ser apropriada ou produzida (para que possa ser apropriada) e que, por ser o que é (ciência), iluminaria o mundo obscuro que existia antes dela (chamar o feudalismo de idade das trevas é uma presunção que tem por objetivo identificar o iluminismo como o movimento que teria por objetivo trazer luz aos homens). Outra possibilidade é ser a ciência a condição de um ou mais sujeitos estarem cientes (terem conhecimento) de algo. A primeira, mais afeita à dimensão do movimento iluminista é, sem dúvida, uma leitura metafísica que, nas suas variantes modernas mais clássicas, teriam em Kant e Hegel seus diferentes fundamentos lógicos. A noção de ser o saber uma espécie de iluminação tem fundamentos religiosos evidentes, principalmente em toda afirmação que associa a divindade ao existir ou ao prover de luz o pecador que vive na escuridão. Tais pressupostos, presentes em quase todas as 
mitologias ou manifestações religiosas, têm no mito da caverna de Platão a sua alegoria mais bem resolvida: os personagens da caverna veem sombras projetadas por uma luz exterior e creem que tais sombras são a verdade do mundo. Essas metáforas milenares só fazem sentido na tentativa de identificar o iluminismo europeu se nos concentrarmos no entendimento do significado de conhecimento no contexto do desenvolvimento da sociedade fabril urbanizada.

Assim, se consideramos Kant como ponto de inflexão, devemos lembrar que seus apriorismos, no limite, levariam-nos a um conhecimento que existe sem que necessariamente haja um sujeito que saiba. Isso faz muito mais sentido no processo de desvendamento do mundo característico do mercantilismo do que no contexto das formas básicas de transformação direta dos elementos da natureza típicas do industrialismo. Assim, creio, a metafísica objetiva de Hegel faz do iluminismo o que de fato ele é: uma sociedade construindo saberes que, por pertencerem a um processo de hegemonização, devem igualmente se tornar hegemônicos. A tese central que estou defendendo aqui é que nem o monoteísmo judaico, nem o budismo ou o iluminismo podem ser entendidos como formas de olhar o mundo que existiriam fora das experiências das sociedades que as criaram e continuam criando, sendo que a produção de tais "entendimentos do mundo" é, ela também, parte da mesma experiência.

Voltemos ao ponto: palavras como luz, iluminação, iluminismo nada mais são do que o uso e o abuso, de caráter fundamentalmente ideológico, de metáforas que certo tipo de pensamento utiliza com o objetivo de projetar a si próprio em detrimento dos demais, sem que necessariamente consigam realizar suas promessas no cotidiano dos povos que as vivem. Sair da escuridão para a luz não é uma prerrogativa budista ou do iluminismo europeu, mas uma proposição que, com diferentes matizes, está associada a todas as formas de pensamento socialmente organizadas de todas as civilizações. De alguma maneira, a forma como cada um de nós vive e a maneira pela qual tais comportamentos são socialmente aceitos envolve a possibilidade de se construir uma razão justificadora, que faz com que nossa vida nos pareça mais justa, verdadeira e iluminada do que a de outras pessoas ou povos. A expansão do monoteísmo judaico (nos formatos básicos do judaísmo, do cristianismo e do islamismo) tem, para suas épocas (e, por vezes, se retoma como discurso justificador), a mesma condição de, enquanto manifestações específicas, serem iluminadores e justificadores da conquista de outros povos e, no contexto de suas subordinações, sobressaem diferentes formatos do discurso precípuo da salvação e da evangelização. O meu Deus, para ser meu Deus, tem de existir enquanto tal e, portanto, os deuses dos outros são necessariamente falsos. $\mathrm{O}$ budismo não é diferente quanto às intenções, mesmo que possa ter se diferenciado quanto ao método ${ }^{8}$. A ideia de ciência do iluminismo é, igualmente, justificadora de um tipo de sociedade que, para existir, deve 
eliminar as demais ou, no mínimo, subordiná-las às suas estruturas lógicas pelo caminho da hegemonização de suas estruturas produtivas (a fábrica), sua geograficidade (a cidade), suas formas de reprodução (a mercadoria).

Nada disso, portanto, se resume a uma epistemologia (independentemente da rosa dos ventos que queiramos usar para identifica-las), mas ao fato de fazerem ou não sentido para as pessoas e povos que as assumem como suas.

As verdades de cada povo, desde a expansão mercantil, já não se definem tendo por parâmetro a rosa dos ventos, a qual, desde a sua origem, está associada ao movimento e à cultura geral dos povos mercadores. A noção de direção está muito mais associada ao movimento do ir e vir como uma abstração, mesmo que sua origem esteja na necessidade de chegar a e voltar de um lugar determinado para outro. Tal critério, milenar e associado às antigas estruturas mercantis europeias, nos legou as noções de oriente e ocidente e, mais do que isso, as de oriente próximo, oriente médio e extremo oriente, sendo que cada uma delas carregava (e ainda carrega) consigo conceitos e preconceitos advindos da experiência vivida pelos mercadores. De toda maneira, indicavam direções e lugares diferentes porque identificavam povos e culturas diferentes.

Quando é possível falar português ou espanhol ou inglês até os limites mais meridionais ${ }^{9}$ das terras emersas (considerando que cada uma dessas línguas carrega consigo estruturas lógicas próprias e que as diferenciam do pensar, do falar, do compreender que existiam e, com alguma raridade, ainda existem - nos povos que foram sendo conquistados), vale considerar que o movimento geral provocado por Portugal e Espanha a partir do século $\mathrm{XV}$ já redefiniu o sentido geral de pertencimento e a própria noção de que poderia haver uma só epistemologia no hemisfério sul, o que, de resto, só poderia ser uma proposição daqueles que, simplesmente, desconheciam o hemisfério e colocavam em dúvida a existência de antípodas.

De toda maneira, o melhor é continuarmos lendo o texto de Souza Santos.

Qual dos dois acarreta mais riscos para os que não acreditam nas suas promessas? E, finalmente, porque é que questionar o Iluminismo europeu é ainda hoje, mais de dois séculos depois da sua formulação, tão mais relevante e controverso do que questionar o Iluminismo budista? Será apenas porque a maioria de nós é ontológica, cultural e socialmente eurocêntrica, e não budocêntrica?

As perguntas do sr. Souza Santos são, para dizer o mínimo, irrelevantes. Alguns argumentos já foram desenvolvidos no sentido de identificar que o autor está colocando 
sob o crivo de comparação duas manifestações culturais que, por seus próprios fundamentos históricos, são irredutíveis entre si e que, mesmo que o fossem, isso em nada acrescentaria ao debate antropológico em curso. Em seguida, realçando a última pergunta, vale notar que o pronome pessoal (nós) que ali se encontra está muito distante de ser definido. Quem é nós? Quem são os outros? Eu, como brasileiro que sou e me reconheço, bem como parcela considerável dos que habitam o país em que nasci e fui criado, ao fazer tal reconhecimento e, portanto, aceitar a ideia de que a sociedade na qual me reconheço se organiza na forma de Estado Nacional, uma criação eurocêntrica que define a maior parte das relações políticas contemporâneas? Por fim... budocêntrica em relação a eurocêntrica nada mais é do que um exercício de comparação inviável em seus próprios termos.

Vamos acompanhar a resposta que ele nos oferece.

A força do Iluminismo europeu baseia-se em duas demandas incondicionais: a busca do conhecimento científico, entendido como a única forma verdadeira de conhecimento e como fonte única de racionalidade; e o empenho no sentido de vencer a "escuridão", ou seja, de banir tudo quanto é não-científico ou irracional. A incondicionalidade dessas demandas tem como premissa a incondicionalidade das causas que as orientam. E causas incondicionais levam logicamente a consequências incondicionalmente positivas. Aqui reside a fatal debilidade dessa força tão extrema, o seu calcanhar de Aquiles. Tomar como base uma concepção única de conhecimento e de racionalidade social exige que se sacrifique tudo aquilo que não the é conforme. A natureza sacrificial desta confiança reside em que a tolerância e a fraternidade decorrentes da celebração da liberdade e da autonomia contêm em si a fatal incapacidade de distinguir coerção e servidão de modos alternativos de ser livre ou autônomo. Ambos são concebidos como inimigos da liberdade e da autonomia e, logicamente, tratados com desapiedada intolerância e violência. É esse o impulso atávico que subjaz à construção iluminista da humanidade "universal" e o impele a sacrificar alguns humanos, banindo-os da categoria do humano, como o antigo bode expiatório abandonado no deserto. Isso explica a razão pela qual os direitos humanos podem ser violados em nome dos direitos humanos, a democracia pode ser destruída em nome da democracia e a morte pode ser celebrada em nome da vida. Aquilo que torna o Iluminismo europeu tão fatalmente relevante e tão necessitado de constante reavaliação é o fato de, ao contrário de outros projetos iluministas (como o budista), o poder de impor as suas ideias aos outros não se reger, ele próprio, por essas ideias e sim pelo desígnio de prevalecer, se necessário através de uma imposição violenta, sobre aqueles que não acreditam em tais ideias iluminadas ou se veem fatalmente afetados pelas consequências da implementação delas na vida económica, social, cultural e política. 
Esse longo parágrafo me leva a imaginar que, do ponto de vista do sr. Souza Santos, os iluministas seriam os únicos da História da humanidade que, com o objetivo de expandir sua hegemonia, consideraram que o "outro", o diferente, fosse seu inimigo e que, se resiste ao domínio, deve ser morto, e se não resiste, deve ser escravo. Fico a imaginar se, de toda maneira, não teria sido esse o projeto e a prática comum do Império Romano, do Império Otomano, do Império Mongol ou do Império Chinês (deixemos os impérios que se constituíram no continente africano ou entre Maias e Astecas). Talvez tenhamos de pensar em situações mais contemporâneas, como as associadas ao Boko Haran ou ao Estado Islâmico - para nos atermos ao senso comum da imprensa internacional - e é bem provável que possamos colocar em dúvida se o problema da dominação imperialista se resume aos conceitos de verdade e racionalidade do iluminismo. Talvez o que the falte seja compreender que, no interior de toda a violência que se faz em nome do que ele chama de iluminismo, o imperialismo contemporâneo é um dos mais complacentes da História, considerando que os seus fundamentos estão mais voltados à consolidação das formas de produção e reprodução do capital do que, de fato, à perseguição dessa ou daquela manifestação epistemológica. Abusando (eu também) das imagens, creio que para a hegemonia iluminista pouco importa ser muçulmano ou cristão se é possível produzir uniformes para jogadoras de vôlei de praia feminino que possam ser utilizados por qualquer das competidoras ou, mais que isso, se é possível transformar a burca em uma mercadoria sob controle das grandes empresas (muitas delas exploradoras do trabalho infantil).

Vale realçar ainda, e novamente, o problema da luta contra a escuridão, pois é uma motivação presente em todas as ideologias e, portanto, muito distante de ser uma prerrogativa do iluminismo europeu.

Um aspecto mais: vale considerar que, ao diagnosticar como um dos problemas mais graves do iluminismo a busca incondicional do conhecimento científico, o nosso autor assume como seu o mesmo preconceito que dá sentido ao que ele quer combater: a existência de um saber científico ou, em termos já expostos, uma ideia de ciência como uma revelação metafísica cuja apropriação seria a forma pela qual ascendemos ao mundo da luz no formato que ao saber foi dado pelos iluministas e, portanto, desconsidera como ciência todo o saber que é produzido por quaisquer outras epistemologias de tantos e tantos outros povos e, portanto, culturas.

A natureza sacrificial do Iluminismo europeu manifesta-se na forma como raciocina sem razoabilidade, na forma como apresenta as opções que rejeita ou os caminhos que não escolhe como prova da inexistência de outras vias, na forma como justifica resultados catastróficos como danos colaterais inevitáveis. Estas operações traçam uma linha 
abissal entre, por um lado, a luz forte das boas causas e das formas iluminadas de organização social e, por outro, a escuridão profunda das alternativas silenciadas e das consequências destruidoras. Historicamente, o capitalismo, o colonialismo e o patriarcado são as forças principais que têm sustentado a fronteira abissal entre seres totalmente humanos, que merecem a vida plena, e criaturas sub-humanas descartáveis.

Existiria, de fato, uma natureza sacrificial no iluminismo que não tenha se manifestado em outras formações socioeconomicas imperialistas? O que quer dizer o sr. Souza Santos quando afirma que o iluminismo não possui razoabilidade? Qual das verdades reveladas das diferentes civilizações que já existiram ou ainda existam possuiria tal razoabilidade sem que esteja subordinada a outra cultura econômica e militarmente mais importante? Como podemos identificar a luz forte das boas causas? As boas causas são boas para quem? As alternativas silenciadas, por terem sido silenciadas, são necessariamente boas? Uma proposição vaga como esta só pode ser fruto de uma profunda miserabilidade política, uma alternativa que se reproduz fastidiosamente em textos de autoajuda.

$\mathrm{Na}$ sequência, encontramos a afirmação de que o capitalismo, o colonialismo e o patriarcado são, historicamente, a fonte de todo mal.

A oração usa primeiramente de uma vírgula e depois da partícula aditiva "e". Isso, ao que me parece, significa que o autor da frase está se referindo a três substantivos com identidades diferentes e, portanto, não está se referindo necessariamente ao fato do capitalismo ser colonialista e patriarcal. De toda maneira, voltando ao ponto, o capitalismo é uma maneira de viver restrita a um período histórico determinado, enquanto o colonialismo é característica de muitos e vários períodos históricos e o patriarcado tem escalas históricas e geográficas também diferentes. A frase, portanto, carrega em si ambiguidades insuperáveis e não nos permite identificar a que e a quem o sr. Souza Santos está se referindo.

Desdobrando as afirmações, se entendermos que o colonialismo capitalista é uma característica do capitalismo e não se expressa como um fenômeno que se justifica no interior de si mesmo, podemos realçar que todas as sociedades imperialistas da História só o puderam ser porque foram colonialistas e, por fim, que ao destruírem outros povos, subsumi-los, absorvê-los, destruíram, subsumiram e absorveram um complexo conjunto de sociedades patriarcais que, no final das contas, foram silenciadas, redimensionando ou redefinindo o patriarcalismo em seus termos gerais e, principalmente no que se refere à sua prática cotidiana. 
Nos períodos históricos mais recentes, só a título de exemplo, os diferentes patriarcalismos presentes em muitas sociedades tribais e na maior parte dos antigos impérios que existiam nos lugares que vieram a ser chamados de América e África foram destruídos pela expansão colonial capitalista e, sem que tenham desaparecido, foram sendo redefinidos pela prática da vida urbana fundada na produção e circulação de mercadorias ${ }^{10}$.

Por fim, o contraponto idealista chega a afirmar que os iluministas (seja lá quem forem), têm o direito à vida plena. Uma afirmação como esta é, no mínimo, surpreendente. O que seria uma vida plena? No interior da sociedade capitalista, iluminista, patriarcal... quem tem direito a uma vida plena? Isso existe? Existe um modelo de vida plena ou isso se refere ao viver de cada um de nós, com nossas alegrias e dificuldades, com nossos prazeres e angústias e tudo o mais que poderíamos identificar como inerentes ao ato de viver?

Essa linha abissal é uma linha epistêmica. Por isso, a justiça social exige justiça cognitiva e a justiça cognitiva exige que se reconheça que a querela entre a ciência, por um lado, e a filosofia e a teologia, por outro, é um conflito que se enquadra confortavelmente no âmbito da epistemologia iluminista. Aquilo que precisamos de entender é o fato de estes modos de conhecimento se oporem coletivamente a formas de pensamento e sabedorias alheias ao paradigma ocidental. O colonial propriamente dito poderia definir-se em termos dessa terra incógnita epistemológica. Como observou Locke de forma bem reveladora, "No princípio o mundo todo era a América". Longe de representar a superação universal do "estado de natureza" pela sociedade civil, o que o Iluminismo fez foi criar o estado de natureza, consignando-lhe amplas extensões de humanidade e vastos conjuntos de conhecimentos. A cartografia, enquanto disciplina, inscreveu uma demarcação precisa entre a metrópole civilizada e as distantes terras selvagens (americanas, africanas, oceânicas). Esse mundo "natural”, na lógica geotemporal lockiana, tornou-se também uma história "natural". A contemporaneidade e a simultaneidade dos mundos do Outro colonial tornaram-se uma espécie de passado dentro do presente.

Todavia, o sr. Souza Santos não se satisfaz e começa o parágrafo seguinte afirmando que os que têm direito à vida plena e os que não o têm estão separados por uma linha abissal que é uma linha epistemológica. Dessa maneira, o que nos restaria é reivindicar uma justiça cognitiva. E o ponto se repete como um mantra: mudar a maneira de pensar, respeitar os mais diferentes pensares, dar a todos os discursos, valores e práticas cotidianas o direito de existirem seria, de fato, conquistar um mundo mais justo. 
Se o pensar não fosse um entre os mais diversos aspectos do viver, isso talvez tivesse algum sentido. Se não fosse a violência de se ter de viver a cotidianidade do capitalismo a partir de raízes culturais desenvolvidas sob parâmetros absolutamente diferentes uma das características mais complexas dos grandes movimentos migratórios (e me permitam, mais uma vez, usar de imagens mais ou menos literárias), que vai deixando sobre os desertos, montanhas, florestas tropicais ou mares mais ou menos extensos uma imensa mancha constituída pelos mortos que vão ficando pelo caminho, e que assim o fazem na esperança de viverem pelo menos mais um dia, fugindo da fome e das balas e bombas de guerras que avançam em nome do grande capital mas que, no geral, se auto justificam em nome de identidades tribais e da preservação de culturas que não querem ser silenciadas ou de verdades que parecem mais verdadeiras do que outras porque se reconhecem na estrutura produtiva que as engendra. As imagens do menino soldado, empunhando armas sofisticadas e se agrupando em nome de combater o pensamento cristão, ou a do marine americano representando a defesa da democracia é algo que, nesse caso, parece ser a maneira pela qual o tal do iluminismo se consubstancia no interior do continente africano ao mesmo tempo que toma a condição de planetariedade da distribuição territorial das tropas dos EUA e seus aliados, parecem sintetizar uma das maneiras pelas quais a defesa da epistemologia do sul (se é que alguém já descobriu o que é isso) procura seus caminhos de defesa e justiça cognitiva.

Para se chegar ao tipo de pensamento pós-abissal capaz de transcender completamente a oposição binária metropolitano/colonial, é necessário travar uma batalha que excede parâmetros epistêmicos. Apenas se pode confrontar o poder hegemônico através das lutas daqueles grupos sociais que têm sido sistematicamente lesados e privados da possibilidade e do direito de representar o mundo como seu. Os seus conhecimentos, nascidos em lutas anticapitalistas, anticoloniais e antipatriarcais, constituem aquilo a que chamo epistemologias do sul. Tais lutas não se regem por princípios anti-iluministas (a opção conservadora, de direita), mas criam condições para que seja possível uma conversação entre diferentes projetos de Iluminismo, uma ecologia de ideais iluministas.

Nada mais a comentar para além do fato de que os movimentos anticapitalista, anticolonialistas, antipatriarcais nascem, de fato, no interior da hegemonização do capitalismo. Um é condição e desdobramento do outro e só a revolução burguesa nos permitiu identificar que os burgueses são, de fato, reacionários e que é preciso combatêlos, na Europa ou fora dela, como brancos, negros ou de qualquer cor que nossas peles possam ter, de qualquer religião que possamos professar, de qualquer identidade sexual que queiramos fazer parte. O mais importante disso tudo é que a possibilidade dessa luta é, de fato, uma criação da sociedade que a evidencia. As formas anteriores de imperialismo jamais alcançaram a dimensão planetária do capitalismo e não 
consolidaram suas contradições culturais a ponto de tornar evidente que a luta contra o domínio da sociedade capitalista passa, também, pela luta pelo direito à diferença.

Essas diferenças, no entanto, não se expressarão pela garantia de retorno aos mesmos valores que já existiam antes do capitalismo mercantil e seus desdobramentos enquanto sociedade fabril e urbana. Tais formas de preservação carregam consigo os fundamentos da violência associada ao domínio capitalista e seus diferentes modos de viver, justamente aqueles que permitem na exploração do trabalho a acumulação dos meios de exploração. A proposição de uma epistemologia do Sul só faz sentido como uma espécie de mea culpa de quem acredita que exista uma epistemologia do norte e acaba confundindo sabedoria com iluminismo e iluminismo com ciência.

Os conhecimentos nascidos nas lutas apontam para a razoabilidade (troca de razões) e não para racionalidade unilateralmente imposta, e partem das consequências em vez de partirem das causas. A noção de causa enquanto objeto privilegiado de conhecimentoa ideia de que a nossa tarefa consiste em ir cada vez mais fundo até se chegar, por fim, às fundações epistemológicas ou ontológicas, a causa sui ou causa sem causa-é ela própria um artefato da modernidade ocidental. Para os oprimidos, uma epistemologia a partir das consequências torna legível a experiência e possível a justiça. Só assim podem as ruínas converter-se em sementes.

Aqui chegamos ao final e, talvez, à constatação mais cruel: o fato de que mais da metade da humanidade vive hoje em cidades e que uma porcentagem ainda mais elevada vive da produção e consumo de mercadorias, sem que necessariamente esses diferentes povos copartícipes desse processo tenham mudado de língua ou religião (na verdade, o que ocorre é que tais valores estão sendo apropriados e transformados em conteúdo escolar), é a demonstração cabal de que, na História dos imperialismos, nenhum deles chegou ao nível de razoabilidade do capitalismo. Se apropriar da diferença e nela e com ela viver o processo geral de acumulação é a prática hegemônica do pós nazi-fascismo.

Madri, julho de 2018.

\section{NOTAS}

1 - SANTOS, B. S. Pela mão de Alice. O social e o político na transição pós-moderna. São Paulo: Cortez, 1997.

2 - SANTOS, Boaventura de Souza. Em busca de outros iluminismos. Disponível em: $<$ https://outraspalavras.net/destaques/boaventura-em-busca-de-outros-iluminismos/>. Acesso em: 20 jun. 2108. 
3 - Há um outro estranhamento que se refere à ausência de qualquer comentário do autor em relação ao texto de Kant. De toda maneira, considerarei aqui que as ausências serão respeitadas, sob pena destes comentários tornarem-se tão longos a ponto de serem inviáveis.

4 - Evitemos a quase infinita literatura que trata do assunto. Isso nos desviaria definitivamente do tema central destes comentários. Procurei, ao construir conceitos tão aligeirados, dar alguma ideia do que penso sobre os dois temas e as subordinações entre eles.

5 - Sempre imaginando que todas as culturas produzem uma epistemologia.

6 - Fiz o mesmo ao citar Saramago, considerando que meus leitores sabem que estou citando o primeiro (e, até agora, único), lusófono vencedor de um prêmio Nobel de literatura.

7 - Para tanto, teríamos de voltar ao texto de Kant e a sua insistência em chamar a humanidade de covarde e preguiçosa por subordinar-se a gurus ou religiosos de todo tipo e não ter coragem de pensar por si própria. Fica sempre a dúvida do que significaria humanidade para Kant e se os gurus que comandam os preguiçosos e covardes não seriam, também eles, humanos... Contudo, o texto de Kant não faz parte de nossa discussão.

8 - O artigo de Antonio Elorza, publicado no dia 11 de setembro de 2018 no Jornal El País e intitulado "La violencia de Dios" é suficientemente elucidativo em relação ao tema. Consultar em https://elpais.com/elpais/2018/08/28/opinion/1535475279_884522.html e a reportagem de Isabel Ferrer, acessada em 14/09/2018 completará o quadro: https://brasil.elpais.com/brasil/2018/09/13/internacional/1536825301_647257.html

9 - Lembrar que a palavra meridional está associada à experiência europeia de identificar a posição do sol ao meio dia (meridião) com a direção sul e, portanto, nada mais europeu do que chamar o sul de meridional. Acontece que, no limite, sul também é uma palavra europeia.

10 - Estou evitando a todo custo fazer referências bibliográficas, pois isso ampliaria desmesuradamente os comentários que estão sendo feitos. De toda maneira, na contramão desse esforço, fica a indicação do livro de Silvia Federici (Calibán y la bruja - Mujeres, cuerpo y acumulación originaria) onde se defende a tese de que a condição feminina como força de trabalho que produz novos seres humanos para venderem sua força de trabalho estaria na base geral do processo de acumulação primitiva do capital. Fica, portanto, a velha tradição do papel da mulher na sociedade patriarcal visto sob a ótica do que tudo isso significa sob a égide da dominação capitalista. 